\title{
Ionic Basis of Cold Receptors Acting as Thermostats
}

\author{
Makoto Okazawa, ${ }^{*}$ Keizo Takao, ${ }^{*}$ Aiko Hori, Takuma Shiraki, Kiyoshi Matsumura, and Shigeo Kobayashi \\ Division of Biological Information, Department of Intelligence Science and Technology, Graduate School of Informatics, \\ Kyoto University, Kyoto 606-8501, Japan
}

\begin{abstract}
When temperature $(T)$ of skin decreases stepwise, cold fibers evoke transient afferent discharges, inducing cold sensation and heat-gain responses. Hence we have proposed that cold receptors at distal ends of cold fibers are thermostats to regulate skin T against cold. Here, with patch-clamp techniques, we studied the ionic basis of cold receptors in cultured dorsal root ganglion (DRG) neurons of rats, as a model of nerve endings. Cells that increased cytosolic $\mathrm{Ca}^{2+}$ level in response to moderate cooling were identified as neurons with cold receptors. In whole-cell current-clamp recordings of these cells, in response to cooling, cold receptors evoked a dynamic receptor potential $(\mathrm{RP})$, eliciting impulses briefly. In voltage-clamp recordings (-60 $\mathrm{mV})$, step cooling induced an inward cold current $\left(I_{\text {cold }}\right)$ with inactivation, underlying the dynamic RP. $\mathrm{Ca}^{2+}$ ions that entered into cells from extracellular side induced the inactivation. Anal-
\end{abstract}

ysis of the reversal potential implied that $I_{\text {cold }}$ was nonselective cation current with high $\mathrm{Ca}^{2+}$ permeability. Threshold temperatures of cooling-induced $\mathrm{Ca}^{2+}$ response and $I_{\text {cold }}$ were different primarily among cells. In outside-out patches, when T decreased, single nonselective cation channels became active at a critical T. This implies that a cold receptor is an ion channel and acts as the smallest thermostat. Because these thermal properties were consistent with that in cold fibers, we conclude that the same cold receptors exist at nerve endings and generate afferent impulses for cold sensation and heat-gain behaviors in response to cold.

Key words: cold receptor; thermostat; sensor; dorsal root ganglion; phase transition; ionic basis; patch-clamp; thermoregulation
In mammals, heating and cooling of local areas in the hypothalamus, medulla oblongata and spinal cord evoke different heat-loss and heat-gain responses, respectively (Carlisle and Ingram, 1973; Chai and Lin, 1973; Lipton, 1973; Roberts and Mooney, 1974). Thus, multiple thermostats in the CNS regulate core $\mathrm{T}$ with different thermoregulatory effectors (Satinoff, 1978).

In the CNS, there are warm- and cold-sensitive neurons (Nakayama et al., 1963; Hardy et al., 1964; Simon and Iriki, 1971; Inoue and Murakami, 1976), the firing rates (FRs) of which increase with a rise and fall in $\mathrm{T}$, respectively. According to the traditional assumption in physiology (Adrian, 1928), both neurons have been assumed to be sensors (or transducers) of $T \mathrm{~s}$. Investigators hence searched for the multiple thermostats except for these sensor neurons (Hammel et al., 1963; Nakayama et al., 1963; Mitchell et al., 1970; Bligh, 1973) but failed to identify the thermostats (Satinoff, 1978; Kobayashi, 1989).

With extracellular electrodes, impulse activities of warm- and cold-sensitive neurons are recorded in hypothalamic slices (Kobayashi, 1986). The FRs show threshold, saturation, and transient responses to step changes in $\mathrm{T}$. Because $\mathrm{T}$ and FR are not in a one-to-one ratio, it is invalid to assume that both neurons are

Received Oct. 26, 2001; revised Feb. 28, 2002; accepted March 7, 2002.

This study was supported by a grant-in-aid for scientific research from the Ministry of Education, Science, Sports and Culture of Japan, and by Special Coordination Funds for Promoting Science and Technology from the Science and Technology Agency. We thank Dr. S. Nakanishi for invaluable discussions about this manuscript.

*M.O. and K.T. contributed equally to this work.

Correspondence should be addressed to Dr. Shigeo Kobayashi, Division of Biological Information, Department of Intelligence Science and Technology, Graduate School of Informatics, Kyoto University, Sakyo-ku, Yoshida Honmachi, Kyoto 606-8501, Japan. E-mail skoba@i.kyoto-u.ac.jp.

Copyright (C) 2002 Society for Neuroscience $\quad 0270-6474 / 02 / 223994-08 \$ 15.00 / 0$ sensors. Instead, on the basis of control theory (Weyrick, 1975), we propose that warm- and cold-sensitive neurons are the multiple thermostats in the CNS that evoke thermoregulatory responses against heat and cold, respectively (Kobayashi, 1989).

Heating and cooling of skin elicit afferent discharges in warm and cold fibers to evoke heat-loss and heat-gain activities, respectively (Benzinger, 1969; Crawshaw et al., 1975). Their FRs also show threshold and transient responses to step changes in skin T (Hensel and Zotterman, 1951a; Hensel and Huopaniemi, 1969; Schaffer and Braun, 1992). Hence, we propose that warm and cold receptors are peripheral thermostats against heat and cold, respectively (Kobayashi, 1989). A model study easily explains that central thermostat neurons regulate core $T$ s and peripheral thermostat fibers regulate skin $T$ s with thermoregulatory effectors (Kobayashi, 1989).

Despite the significance in $\mathrm{T}$ sensation or thermoregulation, the ionic and molecular basis of warm and cold receptors has not well been characterized, compared with other types of sensory receptors. We have analyzed the ionic basis of warm-sensitive neurons in thin hypothalamic slices with patch-clamp techniques (Hori et al., 1999). Capsaicin receptor (VR1) (Caterina et al., 1997) and its homolog VRL1 (Caterina et al., 1999), cloned from dorsal root ganglion (DRG), respond to noxious heat. In contrast, the ionic basis of central or peripheral cold receptors has not been characterized. Cooling raises the intracellular $\mathrm{Ca}^{2+}$ ion level $\left(\left[\mathrm{Ca}^{2+}\right]_{\mathrm{i}}\right)$ in cultured DRG cells (Suto and Gotoh, 1999). This suggests that cold receptors exist at cell bodies as well as nerve endings in sensory cells. In this study, we analyzed the ionic basis of the cold receptors in cultured DRG cells of rats, as a model of nerve endings, with $\left[\mathrm{Ca}^{2+}\right]_{i}$ measurements (Okazawa et al., 2000) and patch-clamp techniques (Hori et al., 1999). Recently, Reid and Flonta (2001) reported on cold current; however, ion selec- 
tivity of cold currents and single-channel profiles have not been characterized.

\section{MATERIALS AND METHODS}

Procedures were similar to those reported previously (Okazawa et al., 2000). Wistar rats (2-14 d old) were anesthetized with diethyl ether and decapitated. DRGs were isolated and placed in $\mathrm{Ca}^{2+}$-free Krebs' solution (see below) containing $0.25 \%$ collagenase at $37^{\circ} \mathrm{C}$ for $90 \mathrm{~min}$. Thereafter, they were incubated in Krebs' solution containing $0.25 \%$ trypsin at $37^{\circ} \mathrm{C}$ for $15 \mathrm{~min}$, washed in DMEM (Invitrogen), and dissociated by trituration. The DRG cells were then plated on coverslips $(5 \times$ $5 \mathrm{~mm}$ ) coated with poly-L-lysine and cultured in DMEM containing penicillin $(100 \mathrm{U} / \mathrm{ml})$, streptomycin $(0.1 \mathrm{mg} / \mathrm{ml}), 2 \mathrm{~mm}$ L-glutamine, nerve growth factor $(100 \mathrm{ng} / \mathrm{ml}$; Roche Diagnostics), and $10 \%$ fetal bovine serum (Hyclone) at $37^{\circ} \mathrm{C}$ in a humidified atmosphere containing $5 \% \mathrm{CO}_{2}$ for 1-6 d before recordings.

Cultured cells were loaded with $5 \mu \mathrm{M}$ fura-2 $\mathrm{AM}$ (Dojindo) at $30^{\circ} \mathrm{C}$ for $1 \mathrm{hr}$. After washing with Krebs' solution containing (in mM): $136 \mathrm{NaCl}$, $5 \mathrm{KCl}, 2 \mathrm{CaCl}_{2}, 2 \mathrm{MgCl}_{2}, 10$ glucose, 10 HEPES, pH 7.4 adjusted with $\sim 4 \mathrm{NaOH}$, the cell-bearing coverslip was attached with silicone grease to the bottom of a recording chamber mounted on the stage of an upright fluorescence microscope (BS50W I, Olympus). Cells in the chamber were perfused with Krebs' solution by gravity. With a digital image analysis system (AQUACOSMOS; Hamamatsu Photonics), we detected the $\left[\mathrm{Ca}^{2+}\right]_{\mathrm{i}}$ image of cultured DRG cells every $4 \mathrm{sec}$ except for those in Figure $1 F(170 \mathrm{msec})$ and Figure $5(2 \mathrm{sec})$. Cell $\mathrm{T}$ was monitored with a thermocouple $(0.3 \mathrm{~mm}$ in diameter $)$ close to cells.

For cold stimulation, $\mathrm{T}$ was decreased from $30-32^{\circ} \mathrm{C}$ (normal skin temperature) to $13-16^{\circ} \mathrm{C}$ in Figures $1-4$, because these cells have been assumed to be a model of skin receptors. At $30-32^{\circ} \mathrm{C}$, however, responses sometimes started just after cooling, and it was difficult to identify threshold temperatures. To clarify threshold temperatures, $\mathrm{T}$ was decreased from $38-40^{\circ} \mathrm{C}$ to $13-16^{\circ} \mathrm{C}$ in Figures 5-7.

Patch-clamp recordings were similar to those in previous studies (Kobayashi and Takahashi, 1993; Hori et al., 1999). In Figures 1-2, Krebs' solution was used as the extracellular solution. For high $\mathrm{K}^{+}$ solution, $70 \mathrm{~mm} \mathrm{NaCl}$ in Krebs' solution was replaced with equimolar $\mathrm{KCl}$ (see Fig. 1). For $\mathrm{Ca}^{2+}$-free Krebs' solution, $2 \mathrm{mM} \mathrm{CaCl}_{2}$ in $\mathrm{Krebs}^{\prime}$ solution was removed. The standard bath solution to analyze ion channels (see Figs. 3-4, 6-7) was as follows (in mM): $136 \mathrm{NaCl}, 10 \mathrm{HEPES}$, 10 glucose, pH 7.4 adjusted with $\sim 4 \mathrm{NaOH}$. To make the $\mathrm{Ca}^{2+}$ containing solution in Figure $3,2 \mathrm{~mm} \mathrm{Ca}^{2+}$ was added to the standard bath solution. Bath solution to explore $\mathrm{Ca}^{2+}$ permeability in Figure $4 D$ was as follows (in mM): $122 \mathrm{NaCl}, 10 \mathrm{CaCl}_{2}, 0.1 \mathrm{CdCl}_{2}$ to suppress voltage-operated $\mathrm{Ca}^{2+}$ channels (VOCs), 10 HEPES, 10 glucose, pH 7.4 adjusted with $\sim 4 \mathrm{NaOH}$. In inside-out patch recordings (see Fig. $7 F, G$ ), 2 mM EGTA was added to the standard bath solution to keep it in $\mathrm{Ca}^{2+}$-free condition, and $2 \mathrm{~mm}$ EGTA and $1.5 \mathrm{mM} \mathrm{CaCl}_{2}$ were added to the standard bath solution to keep it at $200 \mathrm{~nm}\left[\mathrm{Ca}^{2+}\right]_{\mathrm{i}}$ according to the MAXCHELATOR program (C. Patton, Stanford University: http://www.stanford.edu/ cpatton/maxc.html).

The pipette solution for impulse recordings (see Fig. $1 F$ ) was Krebs' solution. The patch pipette in Figure 2 was filled with a solution containing (in mM): $122 \mathrm{~K}$-gluconate, $14 \mathrm{KCl}, 9 \mathrm{NaCl}, 1 \mathrm{MgCl}_{2}, 0.2 \mathrm{EGTA}$, and 10 HEPES adjusted to $\mathrm{pH} 7.4$ with $\sim 4 \mathrm{KOH}$. The patch pipette in Figures $3 A, 4 A, B, D, 6$, and $7 A-E$ was filled with a low $\mathrm{Cl}^{-}$solution containing (in $\mathrm{mM}$ ): $120 \mathrm{Cs}$-Aspartate, $16 \mathrm{CsCl}, 10$ HEPES, pH 7.4 adjusted with $\sim 4 \mathrm{CsOH}$. In Figure $3 B$, the pipette solution was the low $\mathrm{Cl}^{-}$solution containing $10 \mathrm{~mm}$ BAPTA. In Figures $4 D, 7 F$, and $G$, the pipette was filled with a solution in which $10 \mathrm{mM}$ glucose was removed from the standard bath solution.

Relative permeability of monovalent cation $\left(\mathrm{X}^{+}\right)$to $\mathrm{Cs}^{+}\left(\mathrm{P}_{\mathrm{X}} / \mathrm{P}_{\mathrm{Cs}}\right)$ was calculated as $\mathrm{P}_{\mathrm{X}} / \mathrm{P}_{\mathrm{Cs}}=\exp \left(V_{\text {rev }} F / R T_{\text {abs }}\right)$, where $V_{\text {rev }}$ is the reversal potential, $F$ is Faraday's constant, $R$ is the universal gas constant, and $T_{\text {abs }}$ is the absolute temperature. Relative permeability of $\mathrm{Ca}^{2+}$ to $\mathrm{Cs}^{+}$ $\left(\mathrm{P}_{\mathrm{Ca}} / \mathrm{P}_{\mathrm{Cs}}\right)$ was calculated as described previously (Virginio et al., 1998).

Data were sampled at $0.4 \mathrm{kHz}$ (whole-cell recording) or $2 \mathrm{kHz}$ (singlechannel recording) with MacLab software (AD Instruments) and analyzed with Igor Pro (WaveMetrics). Values were displayed as mean \pm SEM. Statistical significance was obtained with unpaired $t$ test.
A
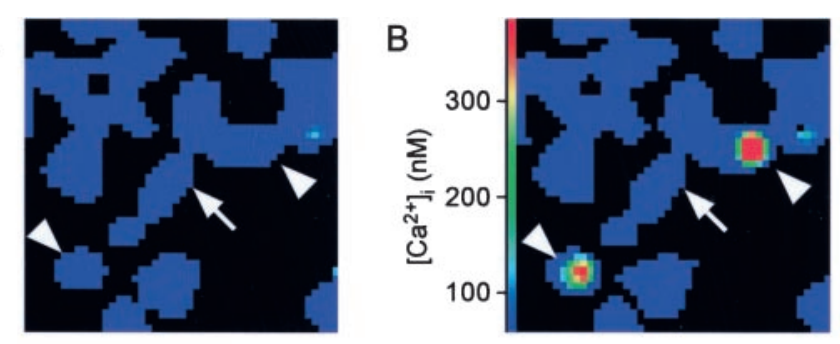

C

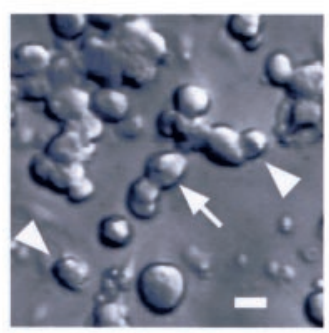

E
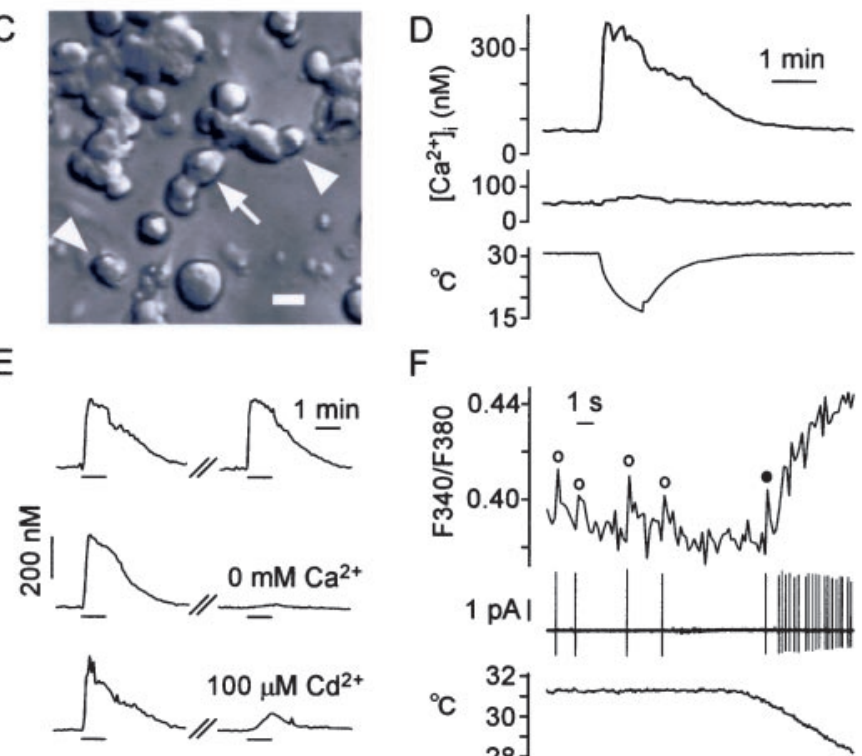

$\mathrm{F}$

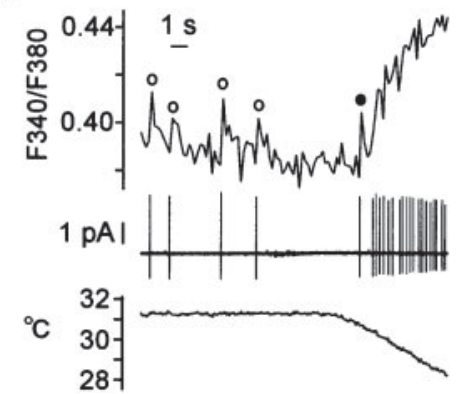

Figure 1. Cooling-induced $\left[\mathrm{Ca}^{2+}\right]_{\mathrm{i}}$ responses in cultured DRG cells. $A-C$, Microscopic views of cells in the same field. $A, B,\left[\mathrm{Ca}^{2+}\right]_{\mathrm{i}}$ in pseudocolor. $A$, Control level of $\left[\mathrm{Ca}^{2+}\right]_{\mathrm{i}} . B$, Cooling-induced $\left[\mathrm{Ca}^{2+}\right]_{\mathrm{i}}$ increase in two cells (arrowheads). We identified them as cold-receptor cells. Arrow indicates one of the cold-insensitive cells. $C$, Nomarski image of cells. Scale bar, $20 \mu \mathrm{m}$. $D$, Time course of $\left[\mathrm{Ca}^{2+}\right]_{\mathrm{i}}$ responses to cooling (bottom) in cold-receptor cells (top) and cold-insensitive cells (middle). E, Pathway of $\mathrm{Ca}^{2+}$ ions to induce $\left[\mathrm{Ca}^{2+}\right]_{\mathrm{i}}$ increase in response to cooling. Top, Control; middle, cooling-induced $\left[\mathrm{Ca}^{2+}\right]_{\mathrm{i}}$ response (left) decreased under $\mathrm{Ca}^{2+}$-free condition (right). Bottom, Cooling-induced $\left[\mathrm{Ca}^{2+}\right]_{\mathrm{i}}$ response (left) decreased by $\mathrm{Cd}^{2+}$ (right), blocker of voltage-operated $\mathrm{Ca}^{2+}$ channels. $F$, Simultaneous recording of impulses (middle) and $\left[\mathrm{Ca}^{2+}\right]_{i}$ increase (top). Impulses were recorded using a cell-attached pipette filled with Krebs' solution. $\left[\mathrm{Ca}^{2+}\right]_{i}$ was measured at a high rate $(170 \mathrm{msec}) . \bigcirc$, $\left[\mathrm{Ca}^{2+}\right]_{\mathrm{i}}$ surge after impulses before cooling; $\mathbf{O},\left[\mathrm{Ca}^{2+}\right]_{\mathrm{i}}$ surge after the first impulse at the onset of cooling.

\section{RESULTS}

\section{Identification of cells with cold receptors}

We searched for cells with cold receptors using $\left[\mathrm{Ca}^{2+}\right]_{\mathrm{i}}$ in cultured DRG cells (Fig. 1). A high $\mathrm{K}^{+}$solution increased $\left[\mathrm{Ca}^{2+}\right]_{\mathrm{i}}$ in neurons (Okazawa et al., 2000; Rusznak et al., 2000) (data not shown). Step cooling (Fig. $1 D$, bottom) rapidly increased $\left[\mathrm{Ca}^{2+}\right]_{\mathrm{i}}$ in a few cells $(13.5 \%)(B)$ of the neurons from a basal level of $69.0 \pm 4.8 \mathrm{nM}($ mean $\pm \mathrm{SEM} ; n=32)$ to a peak of $422.4 \pm 2.9 \mathrm{nM}$ $(D$, top $)$. These cells were small in the cell body $(10-25 \mu \mathrm{m}$ in diameter), which was similar to the previous report (Suto and Gotoh, 1999). After the peak, $\left[\mathrm{Ca}^{2+}\right]_{\mathrm{i}}$ slowly decreased despite a cessation of cooling.

We studied the $\mathrm{Ca}^{2+}$ source that elicited the $\left[\mathrm{Ca}^{2+}\right]_{\mathrm{i}}$ increase in response to cooling (Fig. $1 E$ ). In the middle traces, the coolinginduced $\left[\mathrm{Ca}^{2+}\right]_{\mathrm{i}}$ response (left) disappeared (right) under $\mathrm{Ca}^{2+}$. free conditions $(3.1 \pm 1.1 \%$ of controls; $n=18)$. This suggested that the influx of extracellular $\mathrm{Ca}^{2+}$ ion caused the $\left[\mathrm{Ca}^{2+}\right]_{\mathrm{i}}$ 
increase, consistent with the previous findings (Suto and Gotoh, 1999). In the bottom traces, the cooling-induced $\left[\mathrm{Ca}^{2+}\right]_{\mathrm{i}}$ response (left) was inhibited (right) by $\mathrm{Cd}^{2+}$ ions, a blocker of VOCs (Hoehn et al., 1993; Gotoh et al., 1999). The residual response was $3.0 \pm 1.2 \%$ of controls $(n=17)$ at the time of peak response, suggesting that the VOC is a main pathway for $\left[\mathrm{Ca}^{2+}\right]_{i}$ response.

Cell-attached patch recording of impulses activating VOC and $\left[\mathrm{Ca}^{2+}\right]_{\mathrm{i}}$ measurement were performed simultaneously in the same cold-receptor cells $(n=4)$ (Fig. $1 F)$ (Sugimori and Llinas, 1990). Before cooling, this cell evoked spontaneous impulses (Fig. $1 F$, middle $)$, and $\left[\mathrm{Ca}^{2+}\right]_{\mathrm{i}}$ surges $(\bigcirc)$ occurred immediately after the impulses (top). When $\mathrm{T}$ was decreased (bottom), the impulse activities increased vigorously. A $\left[\mathrm{Ca}^{2+}\right]_{\mathrm{i}}$ surge $(\bigcirc)$ was identified at the first impulse after cooling. Thereafter, $\left[\mathrm{Ca}^{2+}\right]_{\mathrm{i}}$ increased rapidly with impulse activities. These results show that the $\left[\mathrm{Ca}^{2+}\right]$ responses reflect impulse activities.

We performed whole-cell current-clamp recordings in cells with $\left[\mathrm{Ca}^{2+}\right]_{\mathrm{i}}$ responses (Fig. $2 A$, middle). In response to step cooling, membrane potential depolarized from the resting potential $(-65.1 \pm 0.6 \mathrm{mV} ; n=7)$ to a peak $(-32.2 \pm 5.2 \mathrm{mV})$ and slowly decreased. By analogy with other receptors, coolinginduced depolarization may be a receptor potential (RP), showing dynamic response. When the RP became above threshold of excitation, cells generated action potentials (APs) repetitively. However, even when the depolarization continued, firing activities soon decreased (Fig. $2 A$, top), probably because of inactivation of voltage-gated $\mathrm{Na}^{+}$channels (Hille, 1992). Such a marked dynamic response of FR was similar to that of impulses recorded extracellularly in cold fibers in vivo (Hensel and Zotterman, 1951a; Schafer et al., 1982; Schaffer and Braun, 1992). In contrast, cells without $\left[\mathrm{Ca}^{2+}\right]_{\mathrm{i}}$ responses did not respond to cooling $(n=$ 13) (Fig. 2B).

To investigate the ionic basis of the RP, we performed wholecell voltage-clamp recordings $(-60 \mathrm{mV})$ in cells with a $\left[\mathrm{Ca}^{2+}\right]_{\mathrm{i}}$ response. When cooled stepwise, a cold-receptor cell induced an inward current with inactivation (Fig. 2C). The current may be similar to that reported recently (Reid and Flonta, 2001), and we called the current $I_{\text {cold }}$. Peak $I_{\text {cold }}$ was $-25.1 \pm 3.3 \mathrm{pA} / \mathrm{pF}(n=$ 19). This indicated that whole-cell conductance, the reversal potential of which was at a potential depolarized from $-60 \mathrm{mV}$, became active in response to cooling. These results imply that $I_{\text {cold }}$ underlies the RP in current-clamp recordings. In contrast, cooling did not induce a current in cells without a $\left[\mathrm{Ca}^{2+}\right]_{\mathrm{i}}$ response (Fig. 2D) $(n=14)$. Thus, we identified cells with a $\left[\mathrm{Ca}^{2+}\right]_{\mathrm{i}}$ response as neurons with cold receptors, and we identified cells without a $\left[\mathrm{Ca}^{2+}\right]_{i}$ response as cold-insensitive neurons. In the following experiments, we analyzed characters of the cooling-induced $\left[\mathrm{Ca}^{2+}\right]_{\mathrm{i}}$ response and $I_{\text {cold }}$.

\section{Effects of $\mathrm{Ca}^{2+}$ ions on $I_{\text {cold }}$}

When the intravenous $\mathrm{Ca}^{2+}$ ion level decreases, cooling-induced FR increases in cold fibers (Schafer et al., 1982; Schaffer and Braun, 1992). Thus, we studied the effects of the extracellular $\mathrm{Ca}^{2+}$ ion level, $\left[\mathrm{Ca}^{2+}\right]_{\mathrm{o}}$, on $I_{\text {cold }}$ at $-60 \mathrm{mV}$ (Fig. $3 A$ ). The duration of cooling was prolonged to show the inactivation process in full, compared with Figure $2 C$. When $\left[\mathrm{Ca}^{2+}\right]_{\mathrm{o}}$ was normal ( $2 \mathrm{~mm}$ ) (Fig. $3 A$, left), step cooling induced inward $I_{\text {cold }}$ to a peak, which was soon inactivated. At $60 \mathrm{sec}$ after peak, $I_{\text {cold }}$ was $17.0 \pm$ $4.1 \%$ of the peak current $(n=4)$. In $\mathrm{Ca}^{2+}$-free solution (Fig. $3 A$, center), in contrast, cooling induced $I_{\text {cold }}$ without inactivation. When $\left[\mathrm{Ca}^{2+}\right]_{\mathrm{o}}$ was returned to normal, inactivation recovered. The ratio of maximum $I_{\text {cold }}$ in the $\mathrm{Ca}^{2+}$-free solution to the peak
A

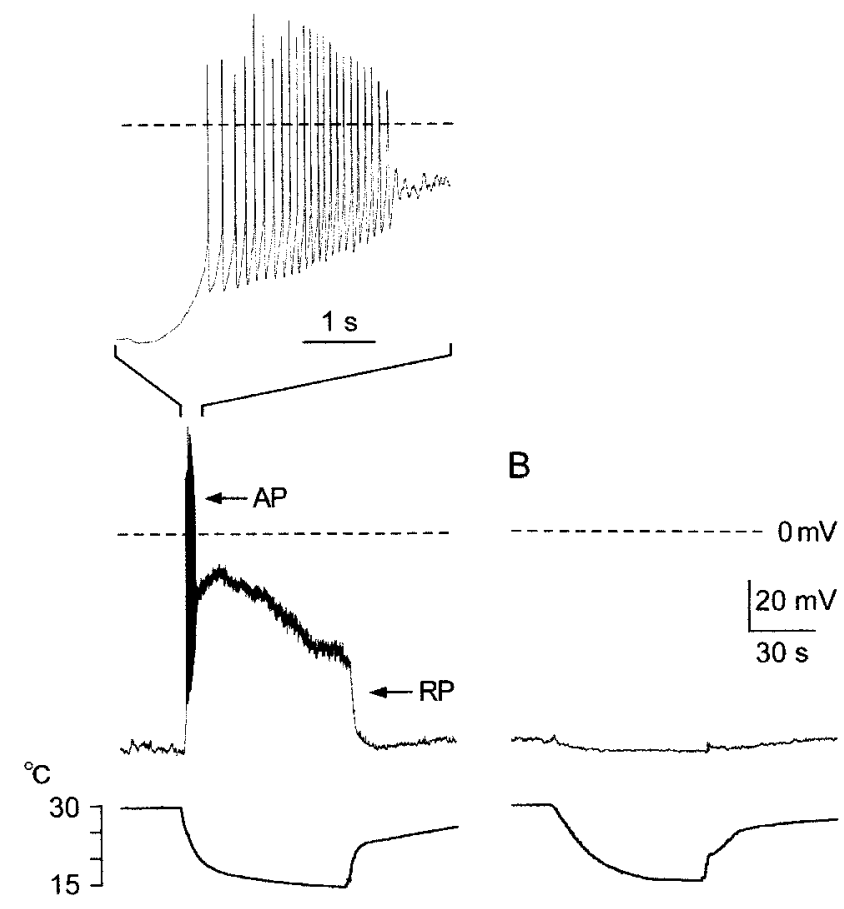

C

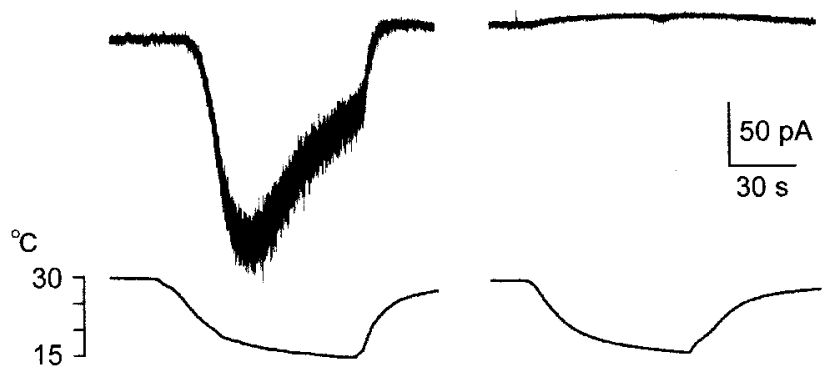

Figure 2. Whole-cell properties of cultured DRG cells. $A, B$, Currentclamp recordings of the membrane potential. $A$, Cold-receptor cell identified by cooling-induced $\left[\mathrm{Ca}^{2+}\right]_{\mathrm{i}}$ increase. Step cooling (bottom) induced a depolarizing receptor potential $(R P)$ with inactivation, which elicited action potentials $(A P)$ briefly at the onset of cooling (middle). The time scale was expanded to show APs (top). Because of cooling-induced dynamic RP and impulses, this cell could not be a sensor. Instead, this cell acted as a thermostat, which generated RPs leading to impulses in response to cooling. $B$, Cells without a cooling-induced $\left[\mathrm{Ca}^{2+}\right]_{\mathrm{i}}$ increase. Cooling did not induce RPs or impulses. $C, D$, Voltage-clamp recordings of the membrane current at $-60 \mathrm{mV}$. $C$, Cold-receptor cell with a cooling-induced $\left[\mathrm{Ca}^{2+}\right]_{i}$ increase. Step cooling induced inward current $\left(I_{\text {cold }}\right)$ with inactivation, underlying dynamic responses of RPs in currentclamp recordings $(A) . D$, Cold-insensitive cell without a cooling-induced $\left[\mathrm{Ca}^{2+}\right]_{i}$ response. Cooling did not induce current.

in normal solution was $1.73 \pm 0.38(n=4)$. Thus, extracellular $\mathrm{Ca}^{2+}$ ions at normal level inactivated $I_{\text {cold }}$, which was consistent with the above in vivo findings (Schafer et al., 1982; Schaffer and Braun, 1992) and the patch-clamp study (Reid and Flonta, 2001). This indicates that $\mathrm{Ca}^{2+}$-induced inactivation of $I_{\text {cold }}$ causes the dynamic response of RP (Fig. $2 A$ ). To clarify whether $\mathrm{Ca}^{2+}$ ions affect $I_{\text {cold }}$ from the intracellular or extracellular side, we added the $\mathrm{Ca}^{2+}$ ion chelator, BAPTA $(10 \mathrm{~mm})$, to the pipette solution. When cytosolic $\mathrm{Ca}^{2+}$ was chelated with BAPTA, $I_{\text {cold }}$ increased to $-68.1 \pm 12.7(\mathrm{pA} / \mathrm{pF})$ without inactivation $(n=4)$, even in the presence of extracellular $2 \mathrm{mM} \mathrm{Ca}^{2+}$ ions (Fig. $2 B$ ). These results 
A

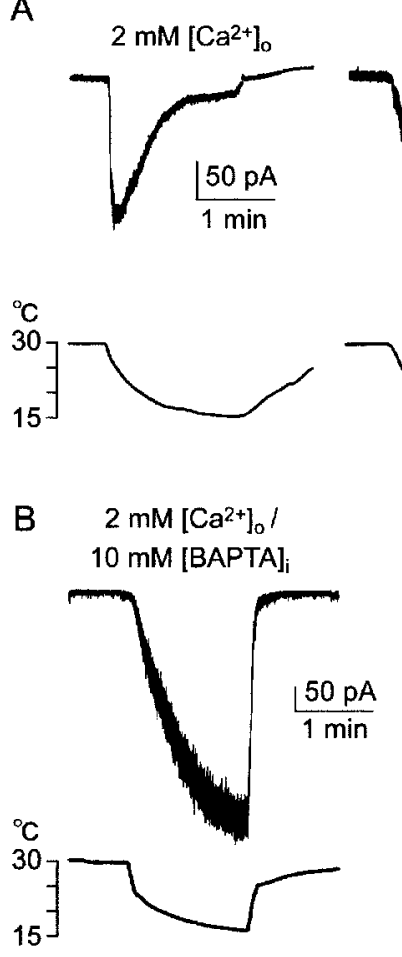

Figure 3. Effects of extracellular $\mathrm{Ca}^{2+}$ ions on $I_{\text {cold }} \cdot A, I_{\text {cold }}$ was inactivated in $\mathrm{Ca}^{2+}$-containing bath solution (left). Duration of cooling was prolonged to clarify the inhibitory process, compared with Figure 2. In $\mathrm{Ca}^{2+}$-free solution, $I_{\text {cold }}$ did not show inactivation (center). When bath solution was returned to $\mathrm{Ca}^{2+}$-containing solution, inactivation of $I_{\text {cold }}$ recovered (right). These responses were obtained in the same cell. $B$, When 10 mM BAPTA was included in a pipette, $I_{\text {cold }}$ was not inactivated in $\mathrm{Ca}^{2+}$-containing bath solution.

imply that $\mathrm{Ca}^{2+}$ ions that enter through $I_{\text {cold }}$ conductance (Fig. $4 D$ ) affect $I_{\text {cold }}$ from the intracellular side.

\section{Ion selectivity of $I_{\text {cold }}$ channels}

We studied ionic selectivity of $I_{\text {cold }}$ conductance by drawing current-voltage $(I-V)$ curves during cooling-induced currents. A set of voltage steps $(25,0,-25,-50,-75$, and $-100 \mathrm{mV} ; 600$ msec) was applied from a holding potential of $50 \mathrm{mV}$. Current evoked at each step was constant for $600 \mathrm{msec}(n=5)$. On the basis of time-independency, we obtained $I-V$ curves with rampvoltage commands changing from 50 to $-100 \mathrm{mV}$ for $600 \mathrm{msec}$ (Fig. 4) (Kobayashi and Takahashi, 1993). In a standard bath solution $\left(140 \mathrm{Na}^{+}\right)$, the $I-V$ curve showed outward rectification (Fig. $4 A$ ). The reversal potential was $0.42 \pm 0.75 \mathrm{mV}(n=16)$, implying that $I_{\text {cold }}$ conductance was nonselective cation conductance. When $140 \mathrm{mM} \mathrm{Na}^{+}$was replaced with equimolar $N$-methylD-glucamine $\left(\mathrm{NMDG}^{+}\right)\left(0 \mathrm{Na}^{+}\right)$, the inward current disappeared $(n=4)$. This suggested that $\mathrm{NMDG}^{+}$or $\mathrm{Cl}^{-}$ions were not permeant through the conductance. When half of the $\mathrm{Na}^{+}$was replaced with equimolar $\mathrm{NMDG}^{+}\left(70 \mathrm{Na}^{+}\right)$, the reversal potential shifted to $-15.9 \pm 0.3 \mathrm{mV}(n=4)$, close to the value $(-16.8 \mathrm{mV})$ estimated by the Nernst equation. When $140 \mathrm{~mm}$ of $\mathrm{Na}^{+}$was replaced with equimolar $\mathrm{Li}^{+}$or $\mathrm{K}^{+}$(Fig. $4 B$ ), the reversal potentials did not shift significantly $\left(\mathrm{Li}^{+}:-1.3 \pm 1.1 \mathrm{mV}, n=5 ; \mathrm{K}^{+}\right.$: $0.8 \pm 1.0 \mathrm{mV}, n=5)$. When internal and external cations were 140 $\mathrm{mm} \mathrm{Na}{ }^{+}$, the reversal potential did not shift significantly $(0.0 \pm 0.7$ $\mathrm{mV}, n=4)$, suggesting that the inward and outward $\mathrm{Na}^{+}$ion permeability was the same (Fig. $4 C$ ). In the presence of $10 \mathrm{~mm}$
A

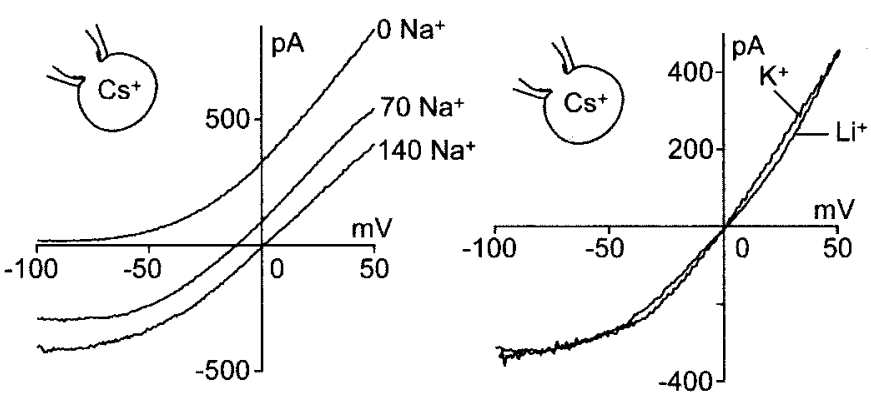

C

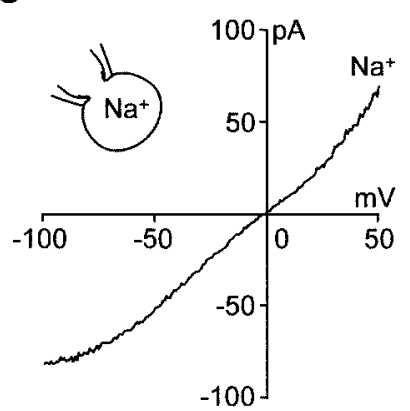

$\mathrm{D}$

D $126 \mathrm{Na}^{2+}$

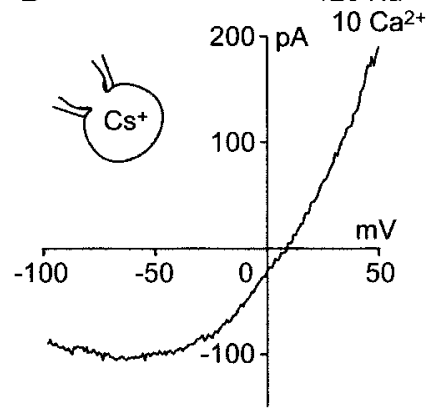

Figure 4. Ion selectivity of $I_{\text {cold }}$ conductance. The $I-V$ curve of $I_{\text {cold }}$ was drawn by application of a ramp-voltage command from 50 to $-100 \mathrm{mV}$ $(0.6 \mathrm{sec}) . A-C, I-V$ curves in the absence of $\mathrm{Ca}^{2+}$ ions in external solution. $A$, In the standard bath solution $\left(140 \mathrm{Na}^{+}\right)$, the $I-V$ curve showed outward rectification. Reversal potential was $0.42 \pm 0.75 \mathrm{mV}(n=$ 16). Replacement of $\mathrm{Na}^{+}$by NMDG abolished inward current $\left(0 \mathrm{Na}^{+}\right)$, indicating that $\mathrm{NMDG}^{+}$or $\mathrm{Cl}^{-}$ions were not permeant. When half of the $\mathrm{Na}^{+}$ions were replaced with $\mathrm{NMDG}^{+}$ions $\left(70 \mathrm{Na}^{+}\right)$, reversal potential shifted close to the value estimated by the Nernst equation. $B$, Replacement of extracellular $140 \mathrm{mM} \mathrm{Na}^{+}$with equimolar $\mathrm{Li}^{+}$or $\mathrm{K}^{+}$did not significantly shift the reversal potential. $C$, When internal and external cations were $140 \mathrm{mM} \mathrm{Na}^{+}$, the reversal potential did not shift significantly. $D, I-V$ curve in the presence of $10 \mathrm{~mm} \mathrm{Ca}^{2+}$ in external solution. Partial replacement of extracellular $\mathrm{Na}^{+}$with $\mathrm{Ca}^{2+}$ shifted the reversal potential to a positive potential.

$\mathrm{Ca}^{2+}$ in bath solution, the reversal potential shifted to a positive potential $(6.8 \pm 0.8 \mathrm{mV} ; n=4)$, indicating that $I_{\text {cold }}$ channel was more permeable to the divalent cations than monovalent cations $\left(\mathrm{P}_{\mathrm{Na}}: \mathrm{P}_{\mathrm{Li}}: \mathrm{P}_{\mathrm{K}}: \mathrm{P}_{\mathrm{Cs}}: \mathrm{P}_{\mathrm{Ca}}=1.02: 0.95: 1.04: 1.00: 8.36\right)$.

\section{Threshold responses of cooling-induced $\left[\mathrm{Ca}^{2+}\right]_{i}$ increase}

The threshold response is a crucial feature of a thermostat. We studied the cooling-induced threshold responses of $\left[\mathrm{Ca}^{2+}\right]_{i}$ increases (Fig. 5) reflecting impulse activities. T was decreased from $38-40^{\circ} \mathrm{C}$ to $13-16^{\circ} \mathrm{C}$ in several steps. When $\mathrm{T}$ decreased below threshold, $\left[\mathrm{Ca}^{2+}\right]_{\mathrm{i}}$ increased transiently (overshoot) and relaxed to a level above basal level. Transient responses in $\left[\mathrm{Ca}^{2+}\right]_{\mathrm{i}}$ may correspond to cooling-induced impulses for a short time (Fig. $2 A$ ). When $\mathrm{T}$ was decreased stepwise, $\left[\mathrm{Ca}^{2+}\right]_{\mathrm{i}}$ showed overshoots repeatedly, similar to firing rate activities in cold fibers in vivo (Dostrovsky and Hellon, 1978). The distributions of threshold temperatures $\left(27.4 \pm 0.6^{\circ} \mathrm{C} ; n=67\right)$ (Fig. $5 B$ ) were skewed to high temperatures. To investigate whether the threshold temperature depends on the changing speed of $\mathrm{T}, \mathrm{T}$ was decreased gradually (Fig. $5 C$ ). When $\mathrm{T}$ decreased below the thresholds, the $\left[\mathrm{Ca}^{2+}\right]_{\mathrm{i}}$ increase showed a long-lasting response. Here, the distributions of threshold temperatures $\left(27.0 \pm 0.5^{\circ} \mathrm{C} ; n=72\right)$ became more symmetrical (Fig. $5 D$ ). However, the mean thresh- 
A
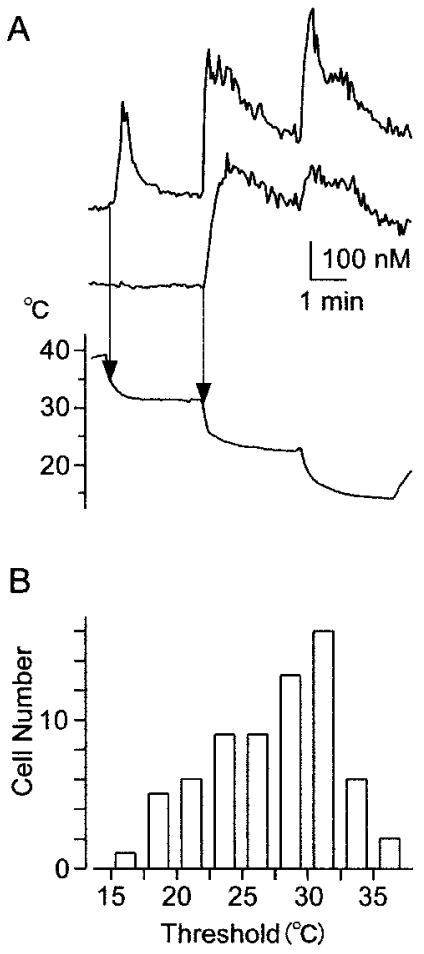

C

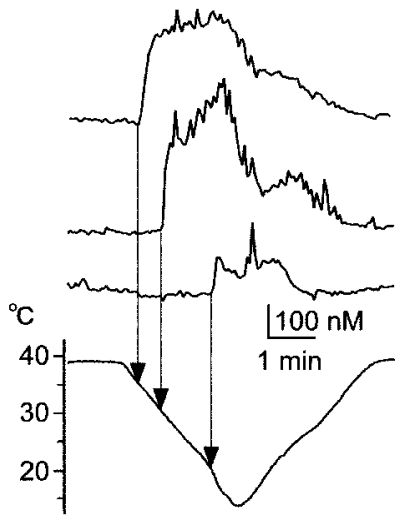

D

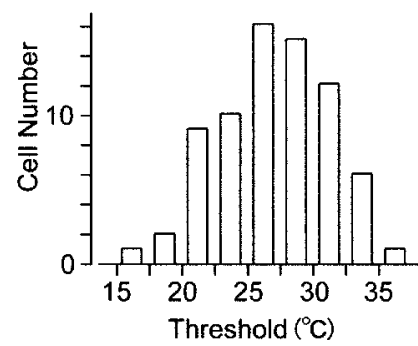

Figure 5. Threshold responses of $\left[\mathrm{Ca}^{2+}\right]_{\mathrm{i}}$ increase reflecting impulse activities. $A$, Simultaneous recordings of $\left[\mathrm{Ca}^{2+}\right]_{\mathrm{i}}$ responses in two cells on the same coverslips. T was decreased stepwise (bottom). When $\mathrm{T}$ decreased below the threshold, $\left[\mathrm{Ca}^{2+}\right]_{\mathrm{i}}$ increased with dynamic responses at the onset of cooling (top). When $\mathrm{T}$ was decreased further to lower steps, $\left[\mathrm{Ca}^{2+}\right]_{\mathrm{i}}$ repeatedly increased with overshoots at the onset of cooling. In another cell (middle), $\left[\mathrm{Ca}^{2+}\right]_{\mathrm{i}}$ increase showed dynamic responses at a lower threshold temperature. $B$, Histogram of threshold temperatures recorded following the same procedure as in $A$. $C$, Simultaneous recordings of $\left[\mathrm{Ca}^{2+}\right]_{\mathrm{i}}$ responses in three cells on the same coverslips. $\mathrm{T}$ was decreased gradually. When $\mathrm{T}$ decreased below a threshold, $\left[\mathrm{Ca}^{2+}\right]_{\mathrm{i}}$ increase showed a long-lasting response. $D$, Histogram of threshold temperatures recorded following the same procedure as in $C$.

old temperatures were not significantly different between the two experiments.

\section{Threshold responses of $I_{\text {cold }}$ in whole-cell recordings}

We analyzed threshold responses of $I_{\text {cold }}$ (Fig. 6), corresponding to that of RP (Fig. 2). In whole-cell voltage-clamp modes (-60 $\mathrm{mV}$ ), $\mathrm{T}$ was decreased stepwise (Fig. $6 A, B$ ). When $\mathrm{T}$ decreased below the thresholds, cells generated $I_{\text {cold }}$ slightly $(A)$. When $\mathrm{T}$ was decreased further to lower steps, $I_{\text {cold }}$ vigorously increased to a peak and then rapidly decreased. The repeated responses may correspond to the repeated $\left[\mathrm{Ca}^{2+}\right]_{\mathrm{i}}$ responses (Fig. 5A). The threshold temperatures $\left(28.7 \pm 0.8^{\circ} \mathrm{C} ; n=12\right)$ were similar to that $\left(28.7^{\circ} \mathrm{C}\right)$ reported by others (Reid and Flonta, 2001) and not significantly different from that $\left(27.4^{\circ} \mathrm{C}\right)$ of the $\left[\mathrm{Ca}^{2+}\right]_{\mathrm{i}}$ response (Fig. 5B). These results suggested that when $\mathrm{T}$ was decreased stepwise below threshold, cold receptors working as a thermostat increased whole-cell conductance with overshoot, leading to the dynamic RP in current-clamp recordings.

To investigate threshold responses without inactivation, $I_{\text {cold }}$ was recorded under $\mathrm{Ca}^{2+}$-free conditions (Fig. $6 C$ ). When $\mathrm{T}$ decreased below the threshold $\left(T_{\mathrm{th}}\right), I_{\text {cold }}$ increased and reached a saturated level $(-33.1 \pm 8.5 \mathrm{pA} / \mathrm{pF} ; n=5)$. The threshold temperatures $\left(27.5 \pm 1.3^{\circ} \mathrm{C} ; n=5\right)$ were not significantly different from the above recordings $\left(28.7^{\circ} \mathrm{C}\right)$, suggesting that external $\mathrm{Ca}^{2+}$ ions did not affect threshold temperatures of $I_{\text {cold }}$.

A

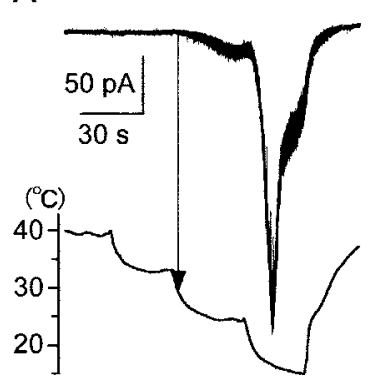

C

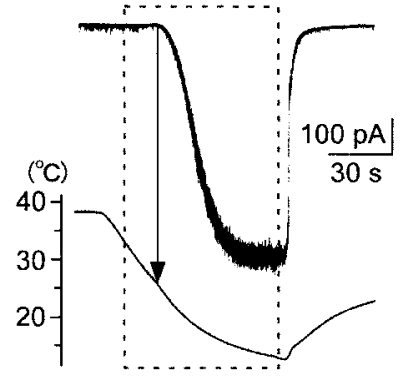

B

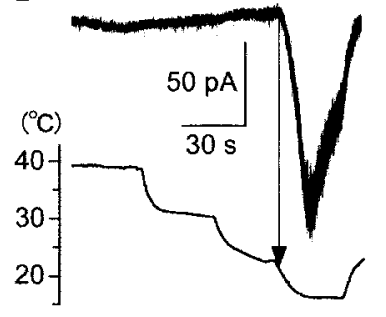

D

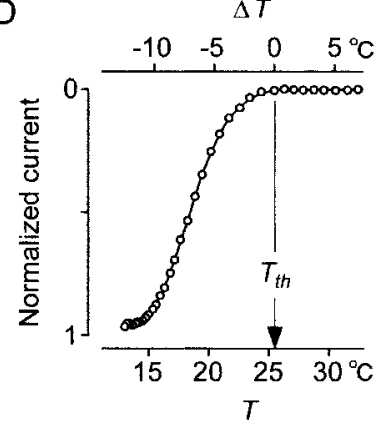

Figure 6. Threshold responses of $I_{\text {cold }}$ in whole-cell voltage-clamp recordings $(-60 \mathrm{mV}) . A, B$, Cells with different threshold temperatures in the $\mathrm{Ca}^{2+}$-containing solution. $A, \mathrm{~T}$ was decreased stepwise. When $\mathrm{T}$ decreased below the threshold (arrow), this cell generated inward $I_{\text {cold }}$ slightly. When $T$ was decreased to a lower step, $I_{\text {cold }}$ vigorously increased to a peak and then rapidly deceased as in Figure $3 A$. $B$, Another cell with a low threshold temperature. $C, I_{\text {cold }}$ in $\mathrm{Ca}^{2+}$-free solution. $\mathrm{T}$ was decreased gradually. Below the threshold $\left(T_{t h}\right)$, inward $I_{\text {cold }}$ increased with a $\mathrm{T}$ decrease and reached saturation. $T_{\mathrm{th}}$ was $25.5^{\circ} \mathrm{C} . D$, Relation between $\mathrm{T}$ (bottom scale) and $I_{\text {cold }}$ in the box in $C$. $\bigcirc$, Experimental values. Top scale shows $\Delta T\left(=T-T_{\mathrm{th}}\right)$. Because of the threshold response, $I_{\text {cold }}$ was expressed by two equations. $I_{\text {cold }}=0$, if $\Delta T>0 . I_{\text {cold }}=S(\Delta T)$, if $\Delta T<$ 0 . $S(\Delta T)$ is an increasing function with saturation.

The relation between $\mathrm{T}$ and $I_{\text {cold }}$ in Figure $6 C$ is shown in Figure $6 D$. We introduced a temperature difference, $\Delta T(=T-$ $\left.T_{\text {th }}\right)$. The top scale shows $\Delta T$. When $T$ is above $T_{\text {th }}, \Delta T>0$. When $T$ is below $T_{\text {th }}, \Delta T<0$. Because of the threshold response, $I_{\text {cold }}$ is expressed by two equations: $I_{\text {cold }}=0$, when $\Delta T>0 ; I_{\text {cold }}=S$ $(\Delta T)$, when $\Delta T<0$.

$S(\Delta T)$ is an increasing function with saturation in the $\mathrm{Ca}^{2+}$-free condition; thus, $I_{\text {cold }}$ depends on a negative value of $\Delta T$. This implies that a cold cell acts as a thermostat, the output of which depends on negative $\Delta \mathrm{T}$ (Weyrick, 1975; Kobayashi, 1989).

\section{Single-channel properties of cold receptors}

We investigated single-channel properties of cold receptors in excised patch recordings of cold-receptor cells (Fig. 7). At a holding potential of $60 \mathrm{mV}$, when $\mathrm{T}$ decreased gradually (Fig. $7 A$ ), single-channel activities suddenly appeared at a critical temperature $\left(T_{\mathrm{c}}\right)$. During the active phase, open and closed states alternated at random. When the channel was open, a unit current flowed outward. Thus, a phase transition from silent to active phases occurred at $T_{\mathrm{c}}$. In 23 patches from 17 cells, $T_{\mathrm{c}}$ was $22.6 \pm$ $1.1^{\circ} \mathrm{C}$, significantly $(p<0.05)$ lower than $T_{\text {th }}$ of whole-cell currents $\left(27.5^{\circ} \mathrm{C}\right) . I-V$ profiles of the unit currents showed outward rectification (Fig. $7 B, C$ ), similar to that of whole-cell currents (Fig. 4). The reversal potential was $-1.1 \pm 0.74 \mathrm{mV}(n=7)$, implying that they were nonselective cation channels. These sim- 
A

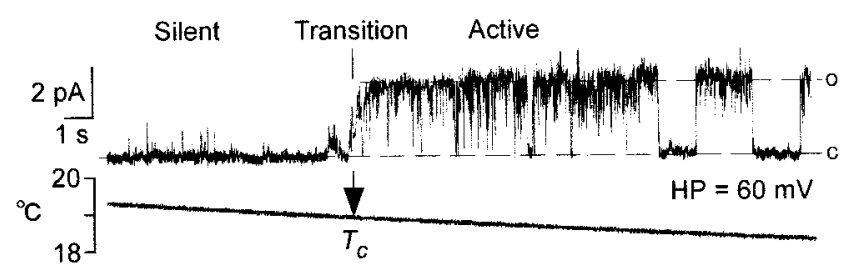

B

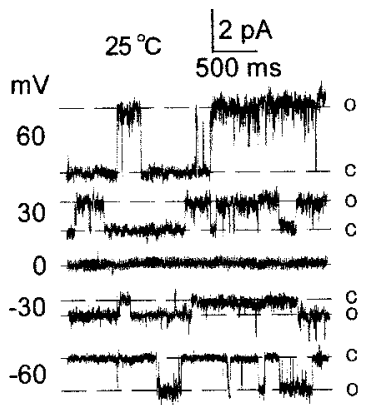

D

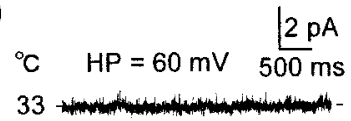

25
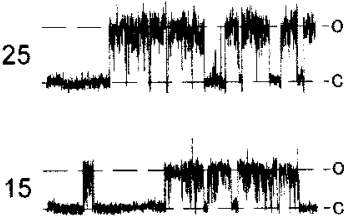

$\mathrm{F}$

$$
\begin{array}{lr}
14^{\circ} \mathrm{C} & \quad 2 \mathrm{pA} \\
\mathrm{HP}=60 \mathrm{mV} & 200 \mathrm{~ms}
\end{array}
$$

(1)

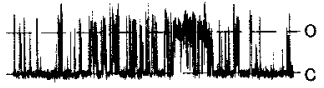

(2)

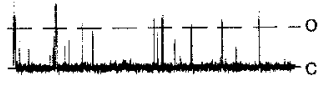

(3)

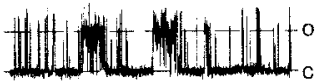

C

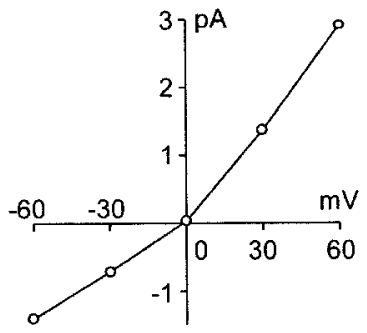

E

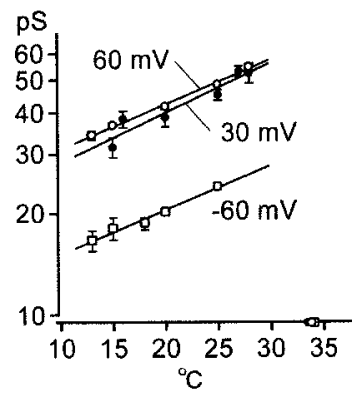

G

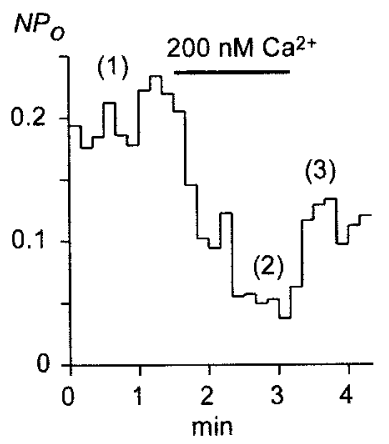

Figure 7. Single $I_{\text {cold }}$ channels in excised patch recordings. $A-E$, Outsideout single $I_{\text {cold }}$ channel recordings. $A$, When $\mathrm{T}$ decreased gradually, single-channel activities started at a critical temperature $\left(T_{c}\right)$, implying that phase transition from silent to active phases occurred at $T_{\mathrm{c}}$. In this patch, $T_{\mathrm{c}}$ was $19^{\circ} \mathrm{C}$. $B$, Cooling-activated unit currents at different holding potentials at $25^{\circ} \mathrm{C}$. $C, I-V$ curve of unit currents in $B$. Points are expressed in mean \pm SEM. Unit conductance $(\gamma)$ was $48.5 \pm 1.0 \mathrm{pS}$ at $60 \mathrm{mV}(n=$ 7) and $23.3 \pm 0.6 \mathrm{pS}$ at $-60 \mathrm{mV}(n=7) . D$, Cooling-induced changes in the size of unit currents. Unit current at $25^{\circ} \mathrm{C}$ was larger than that at $15^{\circ} \mathrm{C}$. $E$, Relationship between $\mathrm{T}$ and unit conductance $(\gamma, \log$ scale $)$ at three holding potentials. Symbols represent mean \pm SEM $(n=7-9)$. Regression lines were drawn by the least square method. $\bigcirc,(60 \mathrm{mV}): \gamma=22.92$ $\exp (0.03076 T) \cdot \bullet,(30 \mathrm{mV}): \gamma=20.14 \exp (0.03441 T) . \square,(-60 \mathrm{mV}): \gamma=$ 11.17 exp $(0.03050 T) . F$, Inside-out single $I_{\text {cold }}$ channel recordings in the absence $(1,3)$ and presence (2) of $200 \mathrm{nM} \mathrm{Ca}^{2+}$ ions in bath solution. $G$, Open probability $\left(N P_{o}\right)$ of the channels $(F)$ plotted against time. Numbered traces in $F$ were obtained at times indicated by respective numbers in $G$. $\mathrm{Ca}^{2+}$ ions (200 nM) decreased open probabilities reversibly.

ilarities of $I-V$ profiles suggested that the unit currents were elements of the whole-cell $I_{\text {cold }}$ current. Thus, cooling-activated channels were recorded in cell-free patches without cytosol, suggesting that cold receptors were ionotropic receptors with nonselective cation channel properties.

When $\mathrm{T}$ was below $T_{\mathrm{c}}$, the size of the unit current decreased with a fall in $\mathrm{T}$ (Fig. $7 D$ ). The relations between $\mathrm{T}$ and unit conductance $(\gamma, \log$ scale) were plotted in Figure $7 E$, indicating that $\gamma$ was exponentially related to $\mathrm{T} . \mathrm{Q}_{10}$ (the $10^{\circ} \mathrm{T}$ coefficient) was $1.36(60 \mathrm{mV}), 1.41(30 \mathrm{mV})$, or $1.36(-60 \mathrm{mV})$.

$\mathrm{Ca}^{2+}$ ions affected $I_{\text {cold }}$ from the intracellular side (Fig. 3B). To clarify whether $\mathrm{Ca}^{2+}$ ions directly inactivated the $I_{\text {cold }}$ channel, we made an inside-out patch configuration from cold-receptor cells. Single-channel activities of $I_{\text {cold }}$ were also recorded in the inside-out patch mode (Fig. $7 F(1))(n=17)$. In three of five patches, $200 \mathrm{nM} \mathrm{Ca}^{2+}$ ions decreased the activities of $I_{\text {cold }}$ channels (Fig. $7 F(2))$. After washout of $\mathrm{Ca}^{2+}$, channel activities recovered (Fig. $7 F(3))$. Open probabilities $\left(N P_{o}\right)$ of the channels were plotted against time (Fig. 7G); $200 \mathrm{nM} \mathrm{Ca}^{2+}$ ions inhibited the channel activities reversibly. However, such an inactivation of $I_{\text {cold }}$ channels was not observed in the remaining two patches. These results imply that intracellular $\mathrm{Ca}^{2+}$ ions partly inactivate single $I_{\text {cold }}$ channels, but soluble substances are also needed in the $\mathrm{Ca}^{2+}$-induced inhibition.

\section{DISCUSSION}

When skin $\mathrm{T}$ decreases stepwise, cold fibers evoke afferent discharges (Hensel and Zotterman, 1951a; Schaffer and Braun, 1992) to induce cold sensation or heat-gain responses (Benzinger, 1969; Crawshaw et al., 1975) for regulation of skin T. Hence we propose that cold fibers themselves are thermostats of skin $\mathrm{T}$ against cold (Kobayashi, 1989). Here we analyzed the ionic basis of cold receptors in DRG neurons in place of nerve endings.

\section{Cold receptors in DRG neurons are the model of that in nerve endings}

In whole-cell current-clamp recordings of cold-receptor neurons in cultured DRG cells, moderate cooling induced dynamic RP, eliciting impulses for a short time (Fig. 2). In some cases, spontaneous activities of discharges were observed (Fig. $1 F$ ). Such a dynamic response and spontaneous activities of discharges have been recorded in cold fibers (Hensel and Zotterman, 1951a; Schaffer and Braun, 1992). When $\mathrm{T}$ was decreased to several steps, dynamic $\left[\mathrm{Ca}^{2+}\right]_{\mathrm{i}}$ responses reflecting FR were evoked each time (Fig. 5), which were similar to the properties of afferent impulses from cold fibers (Dostrovsky and Hellon, 1978). When the extracellular $\mathrm{Ca}^{2+}$ level was normal, $I_{\text {cold }}$ was inactivated (Fig. 3), which was similar to the patch-clamp study (Reid and Flonta, 2001) and consistent with the effects of $\mathrm{Ca}^{2+}$ ions on FR of cold fibers (Schafer et al., 1982; Schaffer and Braun, 1992). Menthol induced an increase in $\left[\mathrm{Ca}^{2+}\right]_{\mathrm{i}}$ and a receptor potential leading to impulses in a small population of DRG neurons (Okazawa et al., 2000). Most of the cold-receptor neurons in this study responded to menthol (our unpublished observation). The observation is consistent with the report that cold fibers respond to menthol (Hensel and Zotterman, 1951b; Schafer et al., 1986). Cold-receptor neurons were small in diameter, implying that cold receptors in DRG neurons are the adequate model of that in nerve endings.

\section{Effects of $\mathrm{Ca}^{2+}$ on $I_{\text {cold }}$}

When the extracellular $\mathrm{Ca}^{2+}$ level was normal, $I_{\text {cold }}$ was inactivated (Fig. 3). This may partially cause adaptation of cold- 
receptor cells (Fig. $2 A$ ). The inactivation disappeared by removing extracellular $\mathrm{Ca}^{2+}$ ions (Fig. $3 A$ ). The disappearance by intracellular BAPTA (Fig. $3 B$ ) indicates that $\mathrm{Ca}^{2+}$ influx causes inactivation of the $I_{\text {cold }}$ channel. In inside-out configurations, the activities of the $I_{\text {cold }}$ channel was suppressed by calcium ions (Fig. $7 E, F)$, indicating that calcium ions directly inactivate the $I_{\text {cold }}$ channels. However, in two of five patches, no obvious inactivation was observed. This suggests that there are other inactivation mechanisms of $I_{\text {cold }}$ channels using calcium-sensitive cytosolic component such as calmodulin or $\alpha$-actinin (Krupp et al., 1999).

\section{Ionic basis of cold receptors}

The reversal potential (near $0 \mathrm{mV}$ ) of $I_{\text {cold }}$ is different from that $(13.3 \mathrm{mV})$ reported by others (Reid and Flonta, 2001). We cannot explain the discrepancy, because the ion compositions of intracellular and extracellular solutions are not described in their paper. The ion selectivity of the $I_{\text {cold }}$ channel was $\mathrm{Ca}^{2+}>\mathrm{Cs}^{+} \sim$ $\mathrm{Li}^{+} \sim \mathrm{K}^{+} \sim \mathrm{Na}^{+}$, indicating that the nonselective cation channel is permeable to both monovalent and divalent cations. Such a high permeability to $\mathrm{Ca}^{2+}$ has been reported in NMDA receptors (Burnashev et al., 1995) and the transient receptor potential (TRP) family, including TRP 4 (Philipp et al., 1996), TRP6 (Inoue et al., 2001), and VR1 (Caterina et al., 1997).

The $I_{\text {cold }}$ channel is similar to VR1 in several ways. Extracellular $\mathrm{Ca}^{2+}$ ions inactivate channel activities, the $I-V$ curve shows outward rectification, and both are nonselective cation channels. The unit conductance of cold-receptor channels (85.3 pS at 66 $\mathrm{mV}$ at $44^{\circ} \mathrm{C}$; extrapolated by thermal sensitivity of unit current in Fig. $7 E)$ is similar to heat-activated conductance $(83.4 \mathrm{pS}$ at 66 $\mathrm{mV}$ at $44^{\circ} \mathrm{C}$ ) in VR1 (Tominaga et al., 1998).

$I_{\text {cold }}$ current recorded in excised patches (Fig. 7) reveals that cooling directly activates cold channel without soluble second messengers. The Q10 of $\gamma(1.36-1.41)$ is similar to that of the $\mathrm{K}^{+}$ (Rodriguez et al., 1998) and $\mathrm{Cl}^{-}$channels (Pusch et al., 1997). This indicates that $\mathrm{T}$ dependence of $\gamma$ in $I_{\text {cold }}$ channels is similar to that in other types of ion channels.

\section{Cold receptors act as thermostats against cold}

Here we summarize the results and discuss the mechanism of how cold receptors act as thermostats against cold. In response to step cooling, cold receptors in cultured DRG neurons elicited a dynamic RP, which induced impulse trains briefly (Fig. 2). The ionic basis of the RP was analyzed. In whole-cell voltage-clamp recordings, cold receptors induced $I_{\text {cold }}$ with inactivation, when $\mathrm{T}$ decreased below threshold temperatures (Fig. 6A,B). An analysis of the reversal potential suggested that $I_{\text {cold }}$ was a nonselective cation current with high $\mathrm{Ca}^{2+}$ permeability. This implies that RP increases from resting potential toward $\sim 0 \mathrm{mV}$, when whole-cell conductance is activated fully by cooling. Threshold temperatures of cooling-induced $\left[\mathrm{Ca}^{2+}\right]_{\mathrm{i}}$ response and $I_{\text {cold }}$ were distributed widely (Figs. 5, 6). We cannot explain the reason for the diversity at present, but the diversity might be caused by differences in channel modification such as glycosylation (Kedei et al., 2001). Large differences in threshold temperatures have been observed in warm- and cold-sensitive neurons recorded extracellularly in hypothalamic slices (Kobayashi, 1986). Thus, individual cold-receptor cells may be thermostat neurons against cold, having different threshold temperatures as targets of $\mathrm{T}$ regulation (Kobayashi, 1989).

In outside-out patch recordings, when $\mathrm{T}$ decreased, a nonselective cation channel became active at a critical $\mathrm{T}$ (Fig. 7). This implies that a cold receptor is an ion channel and acts as the smallest thermostat against cold. Thus, the principle of thermostat action may be attributable to phase transition between silent and active phases occurring at a critical $\mathrm{T}$ in the channel. When many cold receptors exist in a cell membrane, they will form a whole-cell thermostat against cold. Under $\mathrm{Ca}^{2+}$-free conditions, whole-cell current increased when $\mathrm{T}$ decreased below threshold (Fig. 6D). In contrast, the unit size of single channels decreased with a fall in $\mathrm{T}$ when the channel was active (Fig. $7 E$ ). The discrepancy can be explained as follows. Whole-cell current is equal to $N p_{\mathrm{o}} i$, where $N$ is the number of activated channels, $p_{\mathrm{o}}$ is open probability of the channels, and $i$ is the size of unit currents. Because whole-cell current $\left(N p_{\mathrm{o}} i\right)$ greatly increases with a decrease in $\mathrm{T}$ (Fig. $6 C, D$ ), a cooling-induced increase in $N p_{\mathrm{o}}$ (activities of $N$ channels) may be larger than an cooling-induced decrease in $i$.

We conclude that the same cold receptors as identified in cultured DRG cells exist at nerve endings and generate RP to evoke afferent impulses for cold sensation or heat-gain responses in response to cold.

Note added in proof. While this paper was being revised, the molecular basis of cold receptors was reported (McKemy et al., 2002; Peier et al., 2002). Whole-cell properties of cooling-induced currents in the cloned receptors were similar to results in this paper.

\section{REFERENCES}

Adrian ED (1928) The basis of sensation. London: Christophers.

Benzinger TH (1969) Heat regulation: homeostasis of central temperature in man. Physiol Rev 49:671-759.

Bligh J (1973) Temperature regulation in mammals and other vertebrates. Amsterdam: North-Holland.

Burnashev N, Zhou Z, Neher E, Sakmann B (1995) Fractional calcium currents through recombinant GluR channels of the NMDA, AMPA and kainate receptor subtypes. J Physiol (Lond) 485:403-418.

Carlisle HJ, Ingram DL (1973) The effects of heating and cooling the spinal cord and hypothalamus on thermoregulatory behaviour in the pig. J Physiol (Lond) 231:353-364.

Caterina MJ, Schumacher MA, Tominaga M, Rosen TA, Levine JD, Julius D (1997) The capsaicin receptor: a heat-activated ion channel in the pain pathway. Nature 389:816-824.

Caterina MJ, Rosen TA, Tominaga M, Brake AJ, Julius D (1999) A capsaicin-receptor homologue with a high threshold for noxious heat. Nature 398:436-441.

Chai CY, Lin MT (1973) Effects of thermal stimulation of medulla oblongata and spinal cord on decerebrate rabbits. J Physiol (Lond) 234:409-419.

Crawshaw LI, Nadel ER, Stolwijk JA, Stamford BA (1975) Effect of local cooling on sweating rate and cold sensation. Pflügers Arch 354:19-27.

Dostrovsky JO, Hellon RF (1978) The representation of facial temperature in the caudal trigeminal nucleus of the cat. J Physiol (Lond) 277:29-47.

Gotoh H, Kajikawa M, Kato H, Suto K (1999) Intracellular $\mathrm{Mg}^{2+}$ surge follows $\mathrm{Ca}^{2+}$ increase during depolarization in cultured neurons. Brain Res 828:163-168.

Hammel HT, DC J, Stolwijk JAJ, Hardy JD, Stromme SB (1963) Temperature regulation by hypothalamic proportional control with an adjustable set-points. J Appl Physiol 18:1146-1154.

Hardy JD, Hellon RF, Sutherland K (1964) Temperature-sensitive neurones in the dog's hypothalamus. J Physiol (Lond) 175:242-253.

Hensel H, Zotterman Y (1951a) The response of the cold receptors to constant cooling. Acta Physiol Scand 22:96-105.

Hensel H, Zotterman Y (1951b) The effect of menthol on thermoreceptors. Acta Physiol Scand 24:27-34.

Hensel H, Huopaniemi T (1969) Static and dynamic properties of warm fibres in the infraorbital nerve. Pflügers Arch 309:1-10.

Hille B (1992) Ionic channels of excitable membranes, Ed 2. Sunderland, MA: Sinauer.

Hoehn K, Watson TW, MacVicar BA (1993) Multiple types of calcium channels in acutely isolated rat neostriatal neurons. J Neurosci 13:1244-1257.

Hori A, Minato K, Kobayashi S (1999) Warming-activated channels of warm-sensitive neurons in rat hypothalamic slices. Neurosci Lett 275:93-96.

Inoue R, Okada T, Onoue H, Hara Y, Shimizu S, Naitoh S, Ito Y, Mori Y (2001) The transient receptor potential protein homologue TRP6 is 
the essential component of vascular alpha(1)-adrenoceptor-activated $\mathrm{Ca}(2+)$-permeable cation channel. Circ Res 88:325-332.

Inoue S, Murakami N (1976) Unit responses in the medulla oblongata of rabbit to changes in local and cutaneous temperature. J Physiol (Lond) 259:339-356

Kedei N, Szabo T, Lile JD, Treanor JJ, Olah Z, Iadarola MJ, Blumberg PM (2001) Analysis of the native quaternary structure of vanilloid receptor 1. J Biol Chem 276:28613-28619.

Kobayashi S (1986) Warm- and cold-sensitive neurons inactive at normal core temperature in rat hypothalamic slices. Brain Res 362:132-139.

Kobayashi S (1989) Temperature-sensitive neurons in the hypothalamus: a new hypothesis that they act as thermostats, not as transducers. Prog Neurobiol 32:103-135.

Kobayashi S, Takahashi T (1993) Whole-cell properties of temperaturesensitive neurons in rat hypothalamic slices. Proc R Soc Lond B Biol Sci 251:89-94.

Krupp JJ, Vissel B, Thomas CG, Heinemann SF, Westbrook GL (1999) Interactions of calmodulin and $\alpha$-actinin with the NR1 subunit modulate $\mathrm{Ca}^{2+}$-dependent inactivation of NMDA receptors. J Neurosci 19:1165-1178.

Lipton JM (1973) Thermosensitivity of medulla oblongata in control of body temperature. Am J Physiol 224:890-897.

McKemy DD, Neuhausser WM, Julius D (2002) Identification of a cold receptor reveals a general role for TRP channels in thermosensation. Nature 416:52-58.

Mitchell D, Snellen JW, Atkins AR (1970) Thermoregulation during fever: change of set-point or change of gain. Pflügers Arch 321:293-302.

Nakayama T, Hammel HT, Hardy JD, Eisenman JS (1963) Thermal stimulation of electrical activity of single units of the preoptic region. Am J Physiol 204:1122-1126.

Okazawa M, Terauchi T, Shiraki T, Matsumura K, Kobayashi S (2000) l-Menthol-induced $\left[\mathrm{Ca}^{2+}\right]_{\mathrm{i}}$ increase and impulses in cultured sensory neurons. NeuroReport 11:2151-2155.

Peier AM, Moqrich A, Hergarden AC, Reeve AJ, Andersson DA, Story GM, Earley TJ, Dragoni I, McIntyre P, Bevan S, Patapoutian A (2002) A TRP channel that senses cold stimuli and menthol. Cell 108:705-715.

Philipp S, Cavalie A, Freichel M, Wissenbach U, Zimmer S, Trost C, Marquart A, Murakami M, Flockerzi V (1996) A mammalian capacitative calcium entry channel homologous to Drosophila TRP and TRPL. EMBO J 15:6166-6171.

Pusch M, Ludewig U, Jentsch TJ (1997) Temperature dependence of fast and slow gating relaxations of $\mathrm{ClC}-0$ chloride channels. J Gen Physiol 109:105-116.

Reid G, Flonta ML (2001) Cold current in thermoreceptive neurons. Nature 413:480.

Roberts WW, Mooney RD (1974) Brain areas controlling thermoregulatory grooming, prone extension, locomotion, and tail vasodilation in rats. J Comp Physiol Psychol 86:470-480.

Rodriguez BM, Sigg D, Bezanilla F (1998) Voltage gating of Shaker K ${ }^{+}$ channels. The effect of temperature on ionic and gating currents. J Gen Physiol 112:223-242.

Rusznak Z, Harasztosi C, Stanfield PR, Kovacs L, Szucs G (2000) Potassium-depolarization-induced cytoplasmic $\left[\mathrm{Ca}^{2+}\right]$ transient in freshly dissociated pyramidal neurones of the rat dorsal cochlear nucleus. Pflügers Arch 440:462-466.

Satinoff E (1978) Neural organization and evolution of thermal regulation in mammals. Science 201:16-22.

Schafer K, Braun HA, Hensel H (1982) Static and dynamic activity of cold receptors at various calcium levels. J Neurophysiol 47:1017-1028.

Schafer K, Braun HA, Isenberg C (1986) Effect of menthol on cold receptor activity. Analysis of receptor processes. J Gen Physiol 88:757-776.

Schaffer K, Braun HA (1992) Modulation of cutaneous cold receptor function by electrolytes, hormones and thermal adaptation. Physiol Res 41:71-75.

Simon E, Iriki M (1971) Sensory transmission of spinal heat and cold sensitivity in ascending spinal neurons. Pflügers Arch 328:103-120.

Sugimori M, Llinas RR (1990) Real-time imaging of calcium influx in mammalian cerebellar Purkinje cells in vitro. Proc Natl Acad Sci USA 87:5084-5088.

Suto K, Gotoh H (1999) Calcium signaling in cold cells studied in cultured dorsal root ganglion neurons. Neuroscience 92:1131-1135.

Tominaga M, Caterina MJ, Malmberg AB, Rosen TA, Gilbert H, Skinner K, Raumann BE, Basbaum AI, Julius D (1998) The cloned capsaicin receptor integrates multiple pain-producing stimuli. Neuron 21:531-543.

Virginio C, North RA, Surprenant A (1998) Calcium permeability and block at homomeric and heteromeric $\mathrm{P} 2 \mathrm{X} 2$ and $\mathrm{P} 2 \mathrm{X} 3$ receptors, and $\mathrm{P} 2 \mathrm{X}$ receptors in rat nodose neurones. J Physiol (Lond) 510:27-35.

Weyrick RC (1975) Fundamentals of automatic control. Tokyo: McGraw-Hill Kogakusha. 